\title{
Remembrance and Architecture The House OF FATES PROJECT
}

\author{
Aurél Benárd \\ Institute of Architecture, Ybl Miklós Faculty of Architecture and Civil Engineering, \\ Szent István University, Budapest, Hungary \\ Benard.Aurel@ybl.szie.hu
}

\begin{abstract}
The changes which took place a quarter of a century ago in the countries of Europe's Eastern Bloc transformed the social conventions of the time. A kind of social dialog has been started, about the Holocaust amongst other things. New memorials and monuments dedicated to the Holocaust have been constructed in the countries of the region as a result. Several phases can be identified in the building of monuments to the Holocaust over the past 25 years. These changes in the process of recollection and in the building of the monuments themselves are typified by the House of Fates project. The memorial center was built in Budapest for the 70th anniversary of the Holocaust. But the changes in recollection did not stop there, did not come to a standstill in Hungary. It is a mark of the sensitivity of the subject that although the center was finished by the fall of 2015, it has still not opened its gates to the public. In the meantime the project has appeared in several Hungarian professional journals, however these articles do not venture far beyond the realm of basic description. Here we are attempting to analyze the project architecturally. Our analysis shows how the initial usage of primary symbols turns to more contemplative, more abstract images and devices.
\end{abstract}

Keywords: Holocaust museum, historical railway station, memorial sites, monument, heritage

\section{INTRODUCTION}

The changes which took place a quarter of a century ago in the countries of Europe's Eastern Bloc transformed the social conventions of the time in many areas of intellectual life, and also transformed the process of recollection - just as they did the recollection of the genocide, viewed at the time from a distance of only 45 years. These transformations soon took material and spatial form in the shape of new monuments and memorial sites. But the changes in collective remembrance did not stop there, did not come to a standstill in Hungary. The spaces of recollection, along with the social intellectual environment, are still changing rapidly in comparison to the past.

The memorial sites bearing witness to these new perspectives and soul-searching first came to fruition in the newly reunified Berlin, but soon appeared in several Central and Eastern European locations. One of the newest and most emblematic examples of these is the yet to be opened to the public House of Fates. As well as being published on epiteszforum.hu, the House of Fates has been reviewed in two printed architectural journals, both of which included, in the same issues, compilations of other holocaust memorials - Octogon printed international examples [1], while domestic examples were to be found in a supplement to Magyar Építömüvészet [2]. 


\section{ANTECEDENTS}

The history of the House of Fates project goes back more than ten years, although at that time it was not yet known by that name. The proposed central theme was to be child victims of the Holocaust. Its direct antecedent was an exhibition put on at the House of Terror in 2004, which was later moved on a permanent basis to Hódmezővásárhely, to coincide with the refurbishment of the synagogue there. [3]

The similarity of the project's name to the House of Terror is no coincidence. These twin institutions both commemorate authoritarian regimes of our twentieth century history, or serve to remind us of them. Parallels can also be drawn in the attractive elements and social goals.

Another parallel evident in the name is the similarity with the title of the cult book by Imre Kertész [4], our recently deceased Nobel laureate writer. This controversial similarity erupted in a semantic debate, the discussion of which is outside the scope of this article.

Nevertheless, a significant difference can be detected in these two memorials to dictatorship. Whereas the focal point of the memorial to the soviet type of dictatorship is the display of authority, the recollection of the Nazi dictatorship concerns itself primarily with its innocent and "fateless" victims.

\section{THE SITE}

Perhaps the central position of the victim was also a significant consideration in the choosing of the location. Not in terms of the specific place, but the situation - an abandoned railway station on the edge of town.

In 2012, in preparation for the Hungarian Holocaust Memorial Year, the abandoned building of the Józsefváros Railway Station was earmarked as the new location for the memorial. The area situated between Orczy Square and the Fiumei Road cemetery was the second railway station to be constructed in the capital, the first under control of the Hungarian State Railway, and was originally called Losonci Station after the original destination of the trains departing from there. It is officially registered as a transport monument. The railway facility was put into service in 1867. [5]

Although this station did not play a central role in the deportations, the allocation of this location was not entirely without foundation. This does not weaken the authenticity of the museum function.

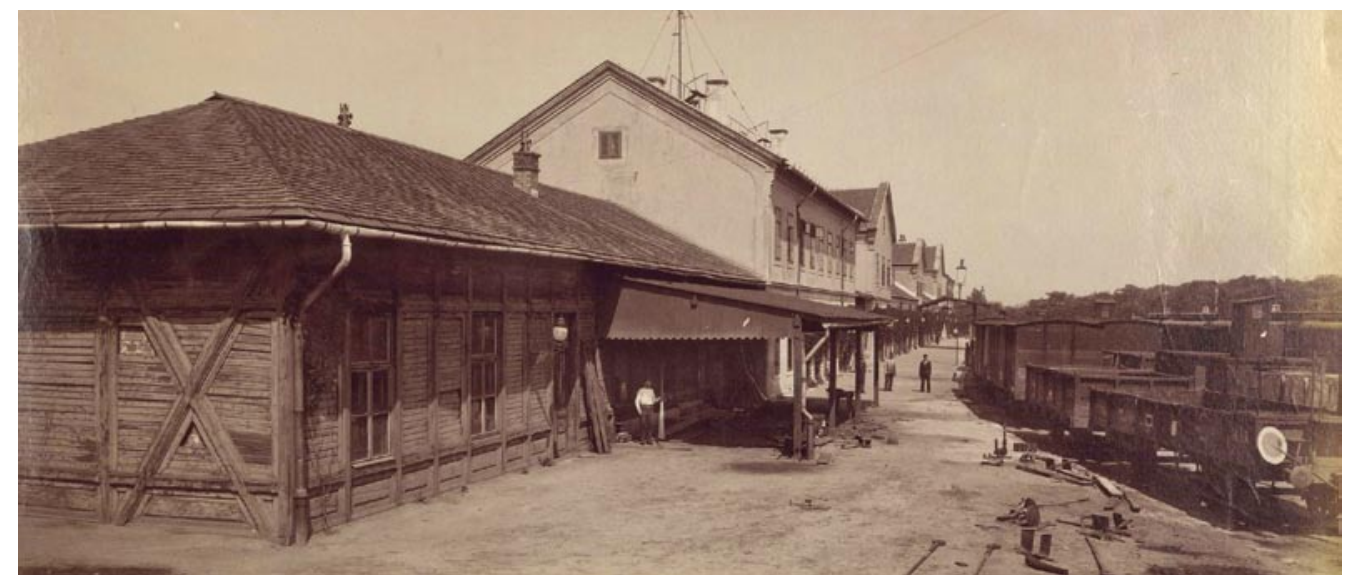

Figure 1. Archive (Józsefváros Railway Station. Photograph taken after 1890. 
"Péter György told the publication Magyar Narancs: the location is problematic in many aspects... but it has one feature which represents a huge possibility, namely the proximity of the National Cemetery. In his opinion, if these two locations were somehow connected, it could be an important gesture - including from the viewpoint of memorial politics." [6]

Péter György's thoughts go far. At the same time, it would also be plausible to highlight and emphasize the symbolic (and not just symbolic) connection with the forgotten, nearby Jewish Cemetery in Salgótarjáni Street, of primary importance for our architectural history as the work of Béla Lajta. György Szegő's article in Magyar Építőmüvészet concurs with this [7].

In the construction of a memorial site, the location of a particular event is essential, but the choosing of locations for museums is often spontaneous. The monuments and memorials of historical military battles are characteristic examples to the former ${ }^{1}$.

In the case of the siting of museums - deriving from our nineteenth century history - the location allocated by the museum's founder, often on land donated specifically for the purpose by a benefactor, is more characteristic. The railway station of Józsefváros is such a place, a location assigned by the museum's founder.

The location, at point where Salgótarjáni Street leads into Fiumei Road, is an impressive edge of town phenomenon, with the seemingly endless boundary wall of the neighboring cemetery, and tram lines disappearing into infinity, apparently leading nowhere. In the second third of the nineteenth century, when the station was built, this really was the edge of town. It is interesting that perhaps because of the area's geographical characteristics, or the cemetery, or the direction and scale of twentieth century development - which in the intervening time has surrounded the city - the area retains this edge-of-town character. Incidentally, there were also burial sites on the land occupied by the railway station before it was built [8].

\section{THE WALK ON THE PATH}

\subsection{Upbeat}

The corner of the site on Salgótarjáni Street is thus a favorable starting point for the visitor from multiple aspects. Much more favorable than the edge of the site close to Orczy Square.

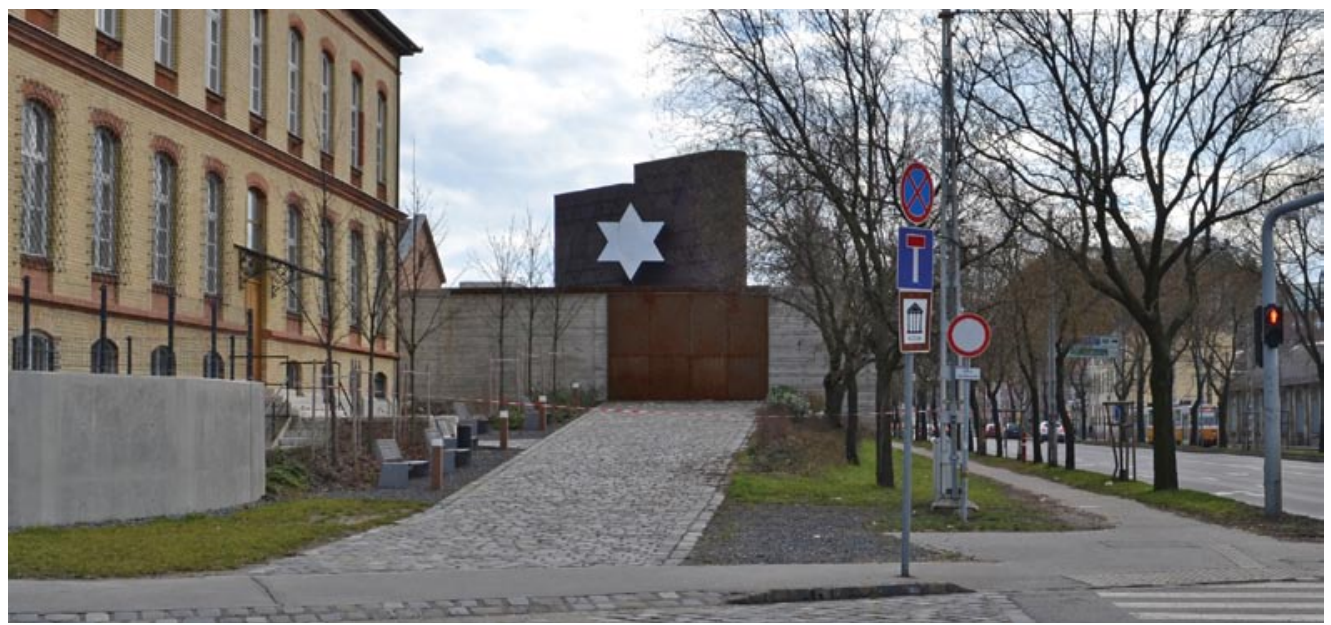

Figure 2. View from Salgótarjáni Street

1 There are counter-examples existing, memorials far away from the place of the past battle, when the events happened in an especially remote location for the people remembering, see the memorial chapel for Don River in Pákozd 
As the museum's visitor entrance, the "ramp", the path ascending in parallel to Fiumei Road, starts from the corner of Salgótarjáni Street. The severity of the ramp is mitigated with benches and small lampposts, and is perhaps a little too gentle in character. A somber steel gate closes its upper end and lets the visitor in. Entering the gate we stand in front of a concrete wall, under a canopy of reinforced concrete. In front of us a shallow but austere stairway, framed by a wide, flat, rusty steel wall, descends to the lower level. The upbeat is dramatic. At the bottom of the stair is the horizontal glass wall of the entrance. Above it is a horizontal platform of loose, rough stone, into which the painstakingly restored nineteenth century station building seems to be sinking.

\subsection{Functional Complexity}

I have mentioned the duality of the museum's function with reference to problems of choosing a location. However, the function is not just dual here, it is even more complex. The House of Fates is part memorial, part museum, and on top of this will have a documentation and research function as well. This group of functions makes it bewilderingly similar to the Páva Street Memorial Center ${ }^{3}$.

\subsection{Elements and Layers}

Our analysis is simplified by the fact that this object can be divided into multiple elements along functional lines. The base layer is the central building of the former railway station built between 1864-67. This consists of three two-storey, transverse gable-roofed buildings and the single-storey structures connecting them; the transverse elements form central and end bays.

Two former ancillary buildings, built at the same time as the central building, are connected symmetrically to its ends. These are longitudinal gable-roofed two-storey structures. These elements are characterized by the rational-romantic features of railway buildings of the erstwhile Habsburg Empire and later Monarchy, with paneled windows and gables decorated with dentil cornices.

The original group of buildings had a longitudinal arrangement parallel to the tracks, but also had a transverse symmetrical axis. This formalist detail was however something of a mannerism, since there is no corresponding spatial development between the west side of the building and Fiumei Road, the symmetrical structure does not assert itself, and Köbányai (later Baross) Street just runs along beside it at a tangent. The elongated chain of buildings running parallel to the tracks was much more decisive.

Subsidiary elements include the two-storey ancillary building built at the end of the nineteenth century at the north, Salgótarjáni Street corner of the site, the twentieth century brick chimney standing next to it, and the locomotive shed, which is now occupied by containers accommodating guestrooms for researchers ${ }^{4}$. Tertiary elements, comprising temporary structures and extensions, were cleared from the site.

2 Railway concept, and a concept also referring to Auschwitz

3 It can't be seen yet how the two institutes will co- (or parallelly) operate, especially because of the fact that the House of

Fates does not yet operate neither as a place of exhibition, nor as a memorial, not even as a research center.

4 This ascetic design of the guest rooms can be connected to the ethos and the function of the institute. 
Further layers were subsequently added to the primary elements.

A butterfly-roofed platform canopy above the former tracks, with its roof rising up towards the edges, belongs to the central building. The part of this canopy which is visible today was built in the 1930s. Between 1884 and 1936 only freight traffic went down here, but passenger traffic was reintroduced at the railway station in 1936 [9]. The monolithic reinforced concrete shell roof was constructed at this time ${ }^{5}$.

Connected to the elements above, forming a new layer, is the newly built exhibition area sunken below the ground floor under the aforementioned rough stone, occupying the space between the building and Fiumei Road. Standing on top of this, as a further additional layer, are the two symbolic, diagonal brick-like towers - as if they were freight wagons standing on end - impaled by a Star of David shaped aluminium shaft. This monumental symbol is the most attractive element in the composition, and will be returned to later.

A multi-layered envelope has been added to the two peripheral buildings: Retro-fitted thermal insulation, a fair-faced concrete shell, and a rusty reinforced concrete haystack-like random mesh, which, as yet another layer, will be covered with some type of creeping plant.

\subsection{Material, Time}

One of the characteristic materials of the House of Fates buildings and environment is steel, the rust surfaced steel COR-TEN, and in many places the untreated steel surface. It is interesting how much it has become the material of our age, and is used in many places for its own sake, as if it were a general problem-solving material. But here it has a serious purpose: without this material, and by the same token some of the other elements, the sight that greets the visitor in the external areas of the museum could easily be reduced to railway romanticism. These elements elevate the building's appearance above that level; the sleepers are not real sleepers, but new logs, the rough stone reminiscent of an oversized embankment, the large stone size forming an impassable terrain. The spaces between the reinforced concrete pillars of the butterfly-roofed canopy of the railway platform are reminiscent of hastily walled-up openings, with a random brick plasticity.

Nor was the waiting room really a waiting room, but it now informs us with a beautiful clock - of the time! The time, which is the most important determinative of Judaism.

\subsection{The Sign}

In front of the buildings, in front of the central bay of the old railway station, stand elements which are easily visible from Fiumei Road. The geometry of the railway cars erected on their ends and turned towards each other is a poetic form, which in addition reveals a kind of industrial beauty. The railway cars are not freight wagons any more, but memorial plaques, or books, "we can associate the sealed columns with books that have spines on both sides, as if hiding "unopenable" and uncrackable secrets." [10]

5 In the middle of the $20^{\text {th }} \mathrm{c}$. this was extended with a prefabricated reinforced concrete girder structure, which followed the arched line of the already winding tracks. The structure was beautiful, but using it, including it in the project would have actually been far gone. 


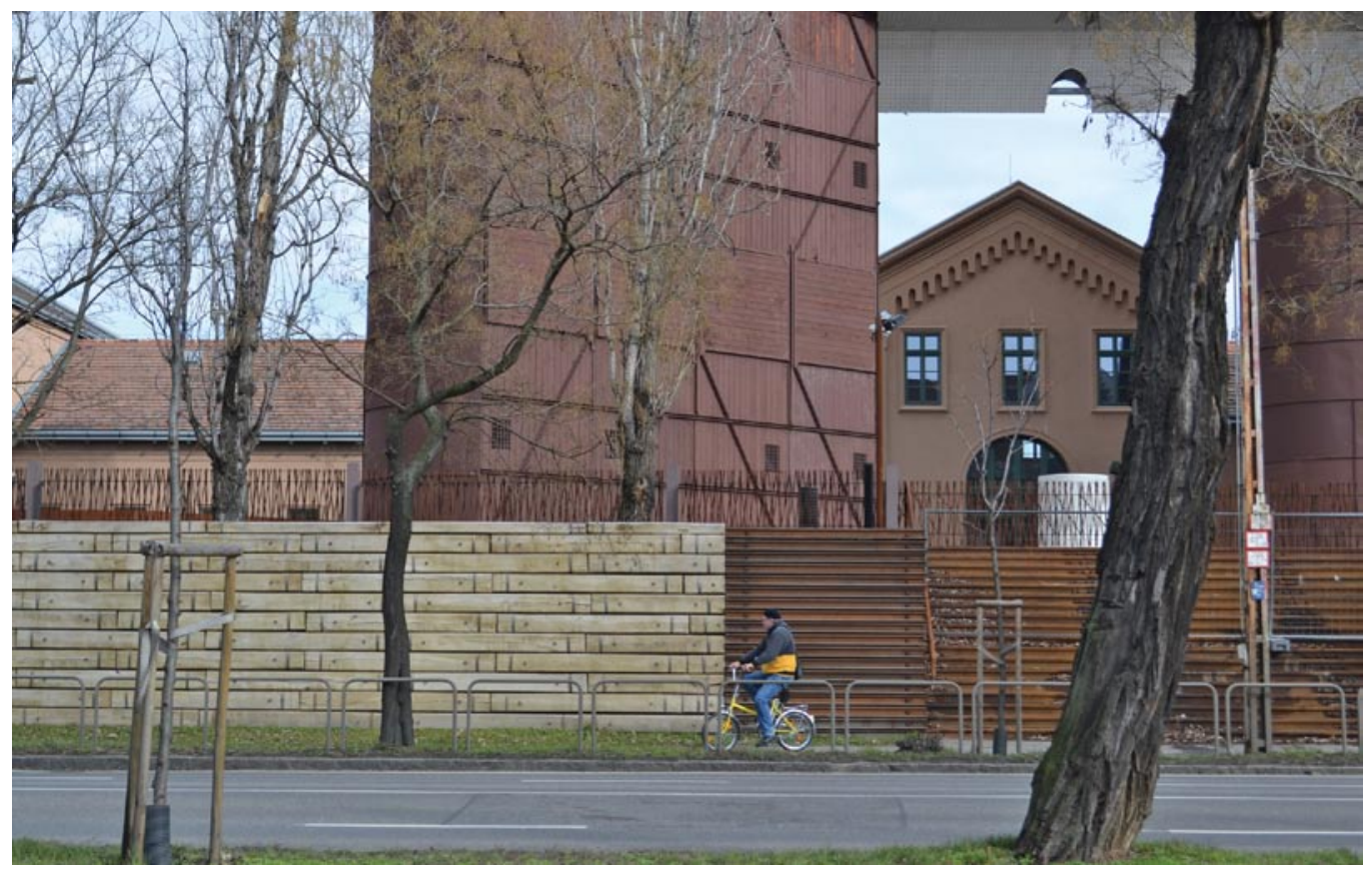

Figure 3. The transverse axis of the building today

The position of the towers and the Star of David shaft, besides being a sign visible from afar, attempts to remedy the aforementioned problem of emphasis on the lateral axis; this symmetrical axis of the building is difficult to perceive, and in addition the direction of approach is perpendicular. It is almost as if the diagonal arrangement of the towers would invert these two directions, however the space for that in front of the building is very tight. Because of this, the towers add tension to the space. This tension could of course be intentional, but as a consequence of this the building of the railway station shrinks, almost becomes incidental at the base of the monumental symbol.

\subsection{The Nineteenth Century and the Museum}

The dignity of the former main building is further weakened by the sculpture-like visual reinforcement of the two peripheral blocks of the original station. These two ancillary buildings are confusing. They differ from the quotation-rich character of the station building, they speak an absolutely contemporary language, even though they were originally nineteenth century buildings. Their exposed concrete shell, constructed with unfinished form-work evoking palisade fencing, their fibrous concrete and steel stacks, the rusty steel sheet lining of their openings does indeed endow them with a new plastic force. This, however, obscures their original monumental character with multiple layers. And these buildings serve only supplementary, subordinate functions, typically consisting of offices and classrooms.

The wagon towers and the wrapping up of the peripheral buildings put the central building of the railway station, the industrial monument, into quotation marks. This technique is wellknown in contemporary architecture. Herzog \& de Meuron used similar techniques to lift the old electricity distribution building above Madrid's Caixa Forum [11] into the present day. 


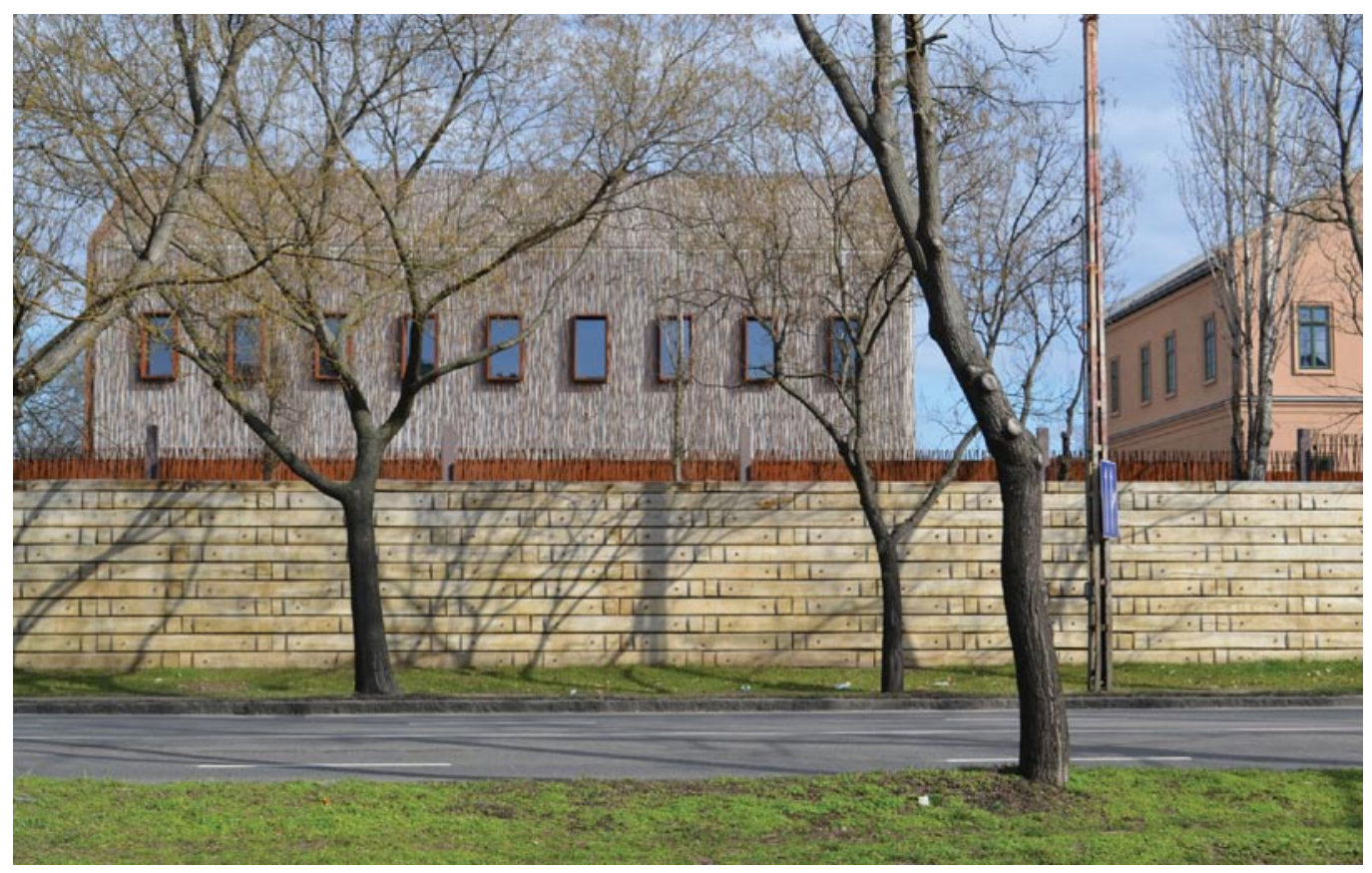

Figure 4. Ancillary building from the side of Fiumei Road

In the lobby of the office building there is an unexpected detail. In one half of the room, where it is possible for guests to wait, the back of the original brick cellar vault was cleaned, and above it a glass ceiling was inserted. The situation is interesting, but it does not give rise to a comforting feeling. It could be considered inconsistent that the original exterior of the building has been detuned by the designers using contemporary techniques, but here they didactically want to display the original structure, the extrados of a simple barrel vault, which was never visible like this, from above. The wish to expose the original structure also appears in the museum café placed on the ground floor of the main building. Here the emergence of the riveted steel structure does produce a rather shocking effect, as if the bare bones of the building were visible in the interior.

\subsection{The Path}

The principal part of the exhibition areas is under the area of rough stone in front of the main building. However, the visitor is then led up into the two towers, apparently made of train cars, standing in front of the main axis of the old building, and is able to cross from one to the other through the bridge in the six-pointed star shaft, and descend from there. According to the designers' statement dramatic installations are being planned for the inside of the towers. Of course it can be sensed here that the wagons aren't real wagons, the wagon sides on the large-scale steel structure are just imitations. This, and the transient, scenery-like, theatrical nature of the planned installations highlights the overemphasized nature of the insides of the towers. Spatially, this is undoubtedly going to be the most intensive section of the exhibition. The towers, just like the Holocaust room of the Jewish Museum in Berlin, are unheated, the path starts upwards as a narrow concrete stairway, then a wrought steel lattice stair leads further along to the fourth level above the ground floor. 
Through the silvery glimmering, lightly perforated shell of the cold star shaft we make our way across to the other tower, then descend on a similarly disorienting stair back to the more protected basement level.

The dramatic power of the two wagon-towers is weakened by the shiny aluminium Star of David shaft, which pierces through both towers, and forms a bridge between them. This way they become a strongly expressive element. The planned light pillar, which will catch the star shaft from below on festive occasions, penetrating it vertically, seems even more problematic: not technically, the vertical duct for the light beam has been formed in the middle of the star. The light pillar was first developed for propaganda purposes (or if you like, for ideological purposes) by Albert Speer, architect of Hitler's Reich, in the opening ceremony of the 1936 Berlin Olympic Games 6 , and afterwards at the Nazi Party Nuremberg Rally.

I have mentioned in the introduction that victim-centered memorials are built to commemorate national socialist tyranny. This light pillar on the other hand could be an element of authoritybased memorials like the statues of the Statue Park of Kamaraerdö. But it hardly fits in the context of victim-centered remembrance.

I think that we will get nowhere with a literal analysis of this triple element group, only a very enforced story can be constructed around it. All in all, these are powerful motifs. Like this, though, it only tries to bring up and evoke impressions. A group of objects invoking primary associations.

\subsection{The Garden Contrast}

Similarly to the elements mentioned above, I consider the garden at the end of the exhibition area above Orczy Square to be a sought-out idea. The garden has a far-eastern flavor, but with a delicate character. Like a pendant of the descending entrance stair, the garden is also sunk below ground level. The garden is charming, with its spherical trimmed hedges and its wood-like promenade, and thus it is difficult to understand. If we are looking for some kind of solace here, then a much more melancholy, contemplative garden would have been more appropriate.

The wall built between the densely spaced columns of the disused platform canopy with "rough movements" and the courtyard bordered by the building are, however, breath-taking. The area of the former tracks is covered by the by now familiar building element, large, loose pieces of rough stone. Only a narrow pathway is left next to the house. The area of stone, the fair-faced concrete fence, the brick wall, the monolithic concrete surface casting a shadow on the butterfly-roofed brick walling, the wall of the nineteenth century railway station constitute a variety of surfaces, but they surround a seemingly homogeneous space, speaking in the same voice. It brings to mind the untouchable nature of a walled yard of a Japanese palace covered only with raked sand. According to Rudolf Klein, the Ryo-an-ji also inspired the architects of the early modern, for example its effect is discernible in the Barcelona pavilion of Ludwig Mies van der Rohe [12].

According to the design concept, the figures of the painter László Fehér will stand in this area. In 1929 in the Barcelona pavilion Georg Kolbe's female nude sculpture stood on a pedestal in the pool surrounded by polished stone walls; here the contoured figures of László Fehér will stand in the stone area surrounded by coarse surfaced walls. This contrasting parallel enhances the overall picture.

$\overline{6 \text { (In the same year when the platform roof was built) }}$ 


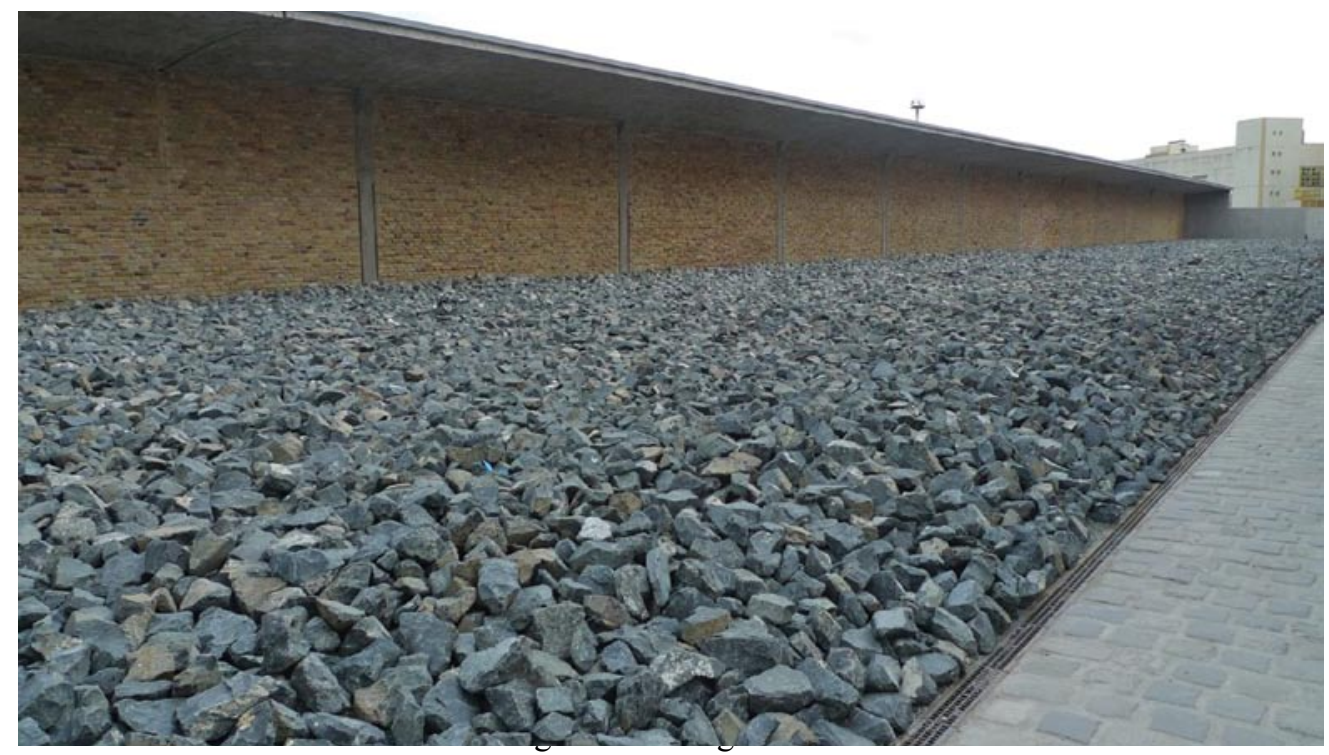

\section{REMEMBRANCE - CONCLUSION}

It is a characteristic feature of museums that they direct the visitor onto some sort of thematic path offered by the designers of the exhibition. Entering onto this path is a time-consuming process, along the way more and more impressions reach the visitor, and this is how he becomes gradually familiar with the exhibition's theme - and also with its space. For the exploration of the space the designer guides the visitor on axes. The axes on the other hand are often broken at right angles, and not just in a single plane, but also in space; gently in the ascent and descent at the entrance, radically and decisively at the entrance to the train car towers.

On the basis of these the museum can be interpreted as a contemporary reinterpretation of baroque architecture. It is a dynamic, temporally aware, emotionally charged, axial architecture, to be interpreted in the context of its environment, although its language is minimalism. It enumerates many minimalist images one after the other. The many, otherwise very beautiful images try to engender attractiveness, as an attempt to turn the museum into some sort of spectacle for enticing tourists. It is an entirely different approach to that of the cemetery-like Holocaust Memorial of Peter Eisenman in Berlin [13]. There, there is a strong concept, a uniform, homogeneous approach. Compared to that, here there is a lot of image and speech. There, there is silence and quiet emptiness.

Jewish culture is a stranger to the image, does not like specific portrayal, although it is not prohibited [14]. Despite the entirely different context, it is easier to identify this character with the work of Eisenman.

Schindler's List was a significant film 22 years ago, of course replete with images as a consequence of its genre. It encouraged many people to get to know that particular period of history. That movie, especially seen from a contemporary viewpoint, spoke of historical events very simply and understandably. 
But "speaking" in images is a defining phenomenon of our time, it is inescapable. In architecture, which is fundamentally a visual act, it is an especially determining factor.

An interesting parallel here is the cinematic work Son of Saul, which speaks with more hidden images about the world of the concentration camp, the horror. The changing of remembrance, the redundancy can be felt in the different perceptions of the two films. This change can also be perceived in the case of memorials. The tendency towards the use of more abstract language is pronounced.

The complex structure of the House of Fates contains multiple forms of remembrance as well. The monumental sign standing in front of the building re-uses a previous idea. The monument erected in front of the Holocaust Museum of Hódmezővásárhely can be considered a scale-model of this. There, there are granite blocks instead of the wagons, but the Star of David shaft impales the two bodies in the same way it penetrates the wagon-towers on Fiumei Road. A similar idea arises in the Ohio state Holocaust monument of Daniel Libeskind, but there only the absence of the shaft traces the Star of David onto the edge of the two slablike blocks [15].

The exhibition area, in particular the courtyard bordered by the platform canopy, commemorate in a reticent, abstract way, even though we are not yet familiar with the materials and installations of the exhibition, and the figures of László Fehér are yet to stand in the stone yard.

\section{REFERENCES}

[1] Gárdonyi, László Megépíteni a kimondhatatlant, ("To build the unspeakable”) Octogon 2015/4. szám, pp. 73-75.

[2] Balogh, László Levente Az utolsó túlélők után - Holokauszt emlékhelyek (“After the last survivors - Holocaust memorials"), Magyar Építőművészet Utóirat melléklet XV. / 83. pp. 28.-38.

[3] 1864-1944-2004-2014 Interjú F. Kovács Attilával (Interview with Attila F. Kovács), Octogon 2015/4. szám, pp. 64-72.

[4] Kertész, ImRE Sorstalanság (Fatelessnes), $1^{\text {st }}$ ed. Magvető, Budapest, 1975

[5] http://www.muemlekem.hu/muemlek?id=11775 [30.05.2016.]

[6] http://magyarnarancs.hu/belpol/koszonet-nelkul-87950_[30.05.2016.]

[7] SzEgö, György A rettenet csend-mintázatai (The silence-patterns of horror), Magyar Építőmüvészet 2015 / 08 pp. 27.

[8] Cadastral map from around 1850, BFL XV. 16b.221/9

[9] http://hu.wikipedia.org/wiki/J\%C3\%B3zsefv\%C3\%A1rosi_p\%C3\%A1lyaudvar [30.05.2016.]

[10] http://epiteszforum.hu/sorsok-haza [30.05.2016.]

[11] https://www.herzogdemeuron.com/index/projects/complete-works/201-225/201-caixaforum-madrid.html [30.05.2016.]

[12] KLEIN, Rudolf Japanese and Western architecture, Cross-fertilisation, Convergence, Synthesis pp. 19. (manuscript)

[13] https://de.wikipedia.org/wiki/Denkmal_f\%C3\%BCr_die_ermordeten_Juden_Europas [30.05.2016.]

[14] KLEIN,

[14] http://emlekezetesztetikaprojekt.blog.hu/2013/08/01/emlekmu_projektterv [30.05.2016.] 


\section{APPENDIX}

\section{Illustrations and Sources}

Figure 1. Archive (Józsefváros Railway Station. Photograph taken after 1890. Fortepan / Budapest Főváros Levéltára, (HU.BFL.XV.19.d.1.07.093)

Figure 2. View from Salgótarjáni Street (author's photo, 14/02/2016)

Figure 3. The transverse axis of the building today (author's photo, 14/02/2016)

Figure 4. Ancillary building from the side of Fiumei Road (author's photo, 14/02/2016)

Figure 5. The "garden" (photo by Tamás Bujnovszky, epiteszforum.hu)

\section{Project Data, List of Project Participants}

Client:

Main Contractor:

Lead Architect, Interior Architect, Designer:

Executive Architect:

Structural Engineer:

Environmental Engineer (waterproofing):

Structural Engineer (glass structures):

Structure:

Building Engineer:

Building Engineer (utilities):

Electrical Engineer:

Electrical Engineer (low voltage):

Lighting Design:

Landscape, Environment.

Historic Monument Consultant:
MÁV Zrt.

SCHEER SÁNDOR, WOLF ANDRÁS, BRÓSZ R. ZSIGMOND (Market Építő Zrt.)

F. KOVÁCS ATTILA (Cube Design Kft.)

REISZ ÁDÁM (fellow architect; FBI Építész Kft.)

HANDA PÉTER

REISCH RICHÁRD, MILE VIKTÓRIA

STOCKER GYÖRGY

PINTÉR SÁNDOR, GERGYE ZOLTÁN (Szigma Stúdio Kft.)

BICSKEI ATTILA, SERES EDIT

BUKOVICS JÁNOS

ÜVEGES ZOLTÁN, FEHÉR SZABOLCS (Artrea Consulting Kft.)

PACHER TIBOR, BÁRDY GÁBOR

MORVAI ZOLTÁN, SZABÓ ESZTER BARBARA, BERECZ BERTALAN

SZLOSZJÁR GYÖRGY, STÉHLI ZOLTÁN

BOR FERENC, TÓTH TÍMEA (Foundation Hild-Ybl) 